\title{
The Impossible Striptease: Nudity in Jean Calvin and Michel de Montaigne
}

\author{
NORA MARTIN PETERSON
}

University of Nebraska-Lincoln

This essay examines the writings of Jean Calvin and Michel de Montaigne, two figures not commonly considered together. The article seeks to highlight a certain fascination with nudity, not only in these texts, but in sixteenth-century culture as a whole. Though it is a bodily phenomenon, I argue, representations of nudity are more than skin-deep; they go beyond the capacity of what the body is able to express. Writings about nudity, whether religious or secular, reflect a widespread anxiety about the relationship between truth and representation in early modern discourse. The preoccupation with surfaces in the texts of both writers highlights the continued epistemological crisis in sixteenthcentury religion, culture, and writing.

Cet essai examine les cuvres de Jean Calvin et de Michel de Montaigne, deux auteurs rarement étudiés dans leur rapport. Cet article cherche à souligner une certaine fascination pour la nudité, non seulement dans ces textes mais dans l'ensemble de la culture du seizième siècle. Bien que la nudité soit observable au niveau corporel, je soutiens que les représentations de la nudité sont bien plus profondes : elles vont au-delà de ce que le corps est capable d'exprimer. Les écrits sur la nudité reflètent une angoisse collective quant à la relation entre vérité et représentation dans le discours des débuts des temps modernes. Le souci lié aux surfaces, présent dans les textes de ces deux auteurs, souligne une crise épistémologique prolongée dans la religion, la culture et la littérature du seizième siècle.

The men, women, and children do not hide any parts of their bodies; what is more, without any sign of bashfulness or shame, they habitually live and go about their affairs as naked as they come out of their mother's womb .... I do not mean, however, to contradict what the Holy Scripture says about Adam and Eve, who, after their sin, were ashamed when they recognised that they were naked, nor do I wish in any way that this nakedness be approved.

-Jean de Léry, History of a Voyage to the land of Brazil. ${ }^{1}$

1. Jean de Léry, History of a Voyage to the land of Brazil, otherwise called America. Containing the navigation and remarkable things seen on the sea by the author; the behaviour of Villegagnon in that country; the customs and strange ways of life of the American savages; together with the description of the 
F arly encounters between native inhabitants of the New World and European Esettlers posed a complex series of questions to settlers. Among them was the problem of nudity: why were natives not ashamed to go about without clothing? Religious accounts, such as the one given by Reformed explorer Jean de Léry above, attempted to reconcile the seemingly shameless natives with the biblical narrative of the fall into original sin, after which innocence was forever rendered impossible. Had these natives somehow managed to escape the postlapsarian shame associated with nudity? Had they been excluded from original sin and all of its problems? Back in Europe, the puzzling lack of dress among New World inhabitants sparked a series of cultural debates. The extent to which religious and secular writers alike took up the trope of nudity points to a shared interest not commonly highlighted in recent scholarship.

The fascination with nudity highlights a problem that is more than merely skin-deep in early modern culture. Something about the naked body both troubles and demands representation. Although writing about nudity already dilutes its supposedly dangerous power by covering it with text, Léry pointedly goes out of his way to reiterate his disapproval. From the passage above, it becomes clear that for sixteenth-century culture, nudity cannot stand on its own. Writings about nudity, then, reflect the accretion of sixteenth-century discourse in general: as the volatility of religious, political, cultural, and scientific discourse increased, so did the number of written attempts to control and categorize the uncertainties surrounding everyday life. Just as writing begets more writing, nudity begets the irrepressible need to add more layers. The interconnectedness of these layers, though it is often twisted, inverted, or denied, illuminates the tensions at work in early modern representations of what it means to be human. On the surface (and nudity appears to be a phenomenon that deals only in surfaces), nudity would seem to depict the simplest state of all: truth, represented on the surface of the body. But in the writings of the sixteenth century, religious and secular alike, nudity is twisted, manipulated, and inverted so frequently that it cannot unambiguously point to any kind of truth or knowledge. Though it is a bodily phenomenon, representations of nudity go beyond the capacity of what the body is able to express.

various animals, trees, plants, and other singular things completely unknown over there (1578), ed. Janet Whatley (Berkeley: University of California Press, 1990), pp. 57, 68. 
Both Jean Calvin and Michel de Montaigne reflect extensively on the role of humans in shaping their own destiny, and they both ultimately share a pessimistic view of human nature. ${ }^{2}$ However, scholars have been reluctant to place their discussions of the human body side-by-side, a fact that highlights, if nothing else, the disciplinary boundaries that have come to separate religion, philosophy, and literature since the Renaissance. When the two writers are read together, which is seldom, it is usually by means of contrast. ${ }^{3}$ The way in which each author confronts nudity highlights the same anxiety of representation as Léry's passage above. In the pages that follow, then, I will explore the ways in which nudity troubles the projects of both thinkers.

Calvin turns to original sin, associating the naked postlapsarian body with the loss of divine knowledge after the fall. Though Adam and Eve gain carnal knowledge, which Calvin associates with the recognition of nudity, their naked bodies (specifically, their genitals) are visually marked with the emblem of sin. But these marks reveal a troubling paradox. Describing God's decision to provide Adam and Eve with clothing to cover the mark of corruption inscribed on their bodies, Calvin ultimately reveals a clothed body in constant need of watchfulness. Even clothes, he argues, cannot prevent man's true nature from coming out. Nudity, whether or not it is covered by clothing, is transformed into a mechanism by which mankind recognizes what she has lost. Knowledge, and nudity, are both coded negatively, and Calvin's representations of knowledge are both interior and exterior, both requiring, and eschewing, the protective veil of clothing.

For Montaigne, nudity can, in a limited way, shed light on an interior that is impossible to excavate rhetorically. Writing over the narrative of original sin, the essayist turns instead to the "savages" of the New World, describing their

2. For a discussion of Montaigne's potential authorship of On Voluntary Servitude (attributed otherwise to La Boétie), see the collection edited by David Lewis Schaefer, Freedom over Servitude (Westport, CT; London: Greenwood Press, 1998). In particular, see pp. 20-21, where Schaefer discusses the implications of the stance in the essay that posits man as the author of his own enslavement (p. 20). Though Calvin would surely agree with the utter departure from biblical tradition, both writers spend time reflecting on the nature and origin of [the lack of] free will. See also the essay by Régine Reynolds-Cornell in the same volume (pp. 115-26), which underscores the evasive "smoke and mirror" techniques Montaigne uses as part of his rhetorical project (p. 126).

3. See p. 136 in Lee Palmer Wandel's recent essay, "John Calvin and Michel de Montaigne on the Eye," in Early Modern Eyes, ed. Walter S. Melion and Lee Palmer Wandel (Leiden: Brill, 2010), pp. 135-55. 
state of nudity as the natural and desirable state of man. He goes on to praise nudity in several of his essays, but his rhetorical refusal or inability to textually de-robe himself completely, and the ironic lens through which he depicts various kinds of nudity, confounds any possible straightforward reading. It also underscores the author's lifelong challenge of uncovering the true essence of man, which appears to be locked inside the body. ${ }^{4}$ Whereas for Calvin, postlapsarian humans are too naked, Montaigne seeks to strip down human nature into its most naked elements.

\section{Postlapsarian nudity in Calvin}

Jean Calvin's Commentaires sur l'Ancien Testament, written around 1555, includes a full volume on Genesis. ${ }^{5}$ Like most other religious writers of his time, Calvin spends a good deal of time glossing the moment of original $\sin .{ }^{6} \mathrm{His}$ main objective in these passages is to highlight the great cost at which humans

4. Recent work has aligned Montaigne's quest for nudity with the philosophy of early modern Cynics (following Diogenes). They see transparency as something desirable, but ultimately completely unrealizable. For example, Hugh Roberts highlights the tendency of these writings to "blur boundaries" between the body and the fluids it contains, and suggests that performances of shamelessness almost (but not quite) invert social structures, just as Montaigne almost (but not quite) reveals himself (p. 596); see "Cynic Shamelessness in Late Sixteenth Century France," The Modern Language Review 99, no. 3 (2004), pp. 595-607. See also pp. 604-07 for Roberts's direct discussion of Montaigne's stance vis à vis the Cynic philosophy. And as Suzel Mayer points out, Montaigne makes a habit of juxtaposing nature with "la vanité des usages sociaux et de certaines doctrines" (the vanity of social customs and of certain doctrines [translation mine]), thus further underscoring the essayist's self-conscious frustration with his inability to arrive at complete transparency. See Mayer's "Un Socrate Cynique," in Le Socratisme de Montaigne, ed. Thierry Gontel and Suzel Mayel (Paris: Garnier, 2010), pp. 219-36, p. 220. For more on the general relevance of Cynics in Renaissance culture, see also Michèle Clément, Le Cynisme à la Renaissance (Geneva: Droz, 2005).

5. Ed. André Malet (Geneva: Fides, 1961). Hereafter cited in the text as Ancien Testament. Alida Leni Sewell has carefully explored the origins of the link between nakedness and shame in Calvin's writings: See chapter 8 of Calvin, the Body, and Sexuality (Amsterdam: VU University Press, 2011), pp. 191-205. Though she oversimplifies the complex relationship in Calvin's writing, ascribing his "sense of shame about the body" to "his personal prudery and prejudices," she nonetheless provides valuable analysis of the sources and societal factors that may have influenced the Reformer's position.

6. The question of what happens after original sin, and how it affects sight and knowledge, is also an issue in book 20 of Calvin's Institutes, especially as it relates to the definition of concupiscence. See Institution de la Religion Chrestienne (1541), ed. Olivier Millet (Geneva: Droz, 2008). Hereafter cited in the text. Calvin writes, 
acquire knowledge. Postlapsarian nudity is the trope within which the paradox of knowledge plays out. Though nudity is the mechanism by which Adam and Eve experience carnal knowledge, its conspicuous absence-the futile attempt to cover their naked bodies before the eyes of God-simultaneously represents the irretrievable loss of divine knowledge. Calvin thus ultimately has no choice but to code human knowledge, especially of the body, negatively. Any kind of human knowledge after the fall is always immediately countered by the steep price humans have to pay for their sin.

Calvin chooses to represent the moment of recognition as one of clarity, and the passage describing the consequences of original sin highlights the visual significance of the moment. The subheading to the gloss reads, "Lors les yeux d'eux deux furent ouverts" (Thenceforth, the eyes of them both were opened). ${ }^{7}$ Calvin connects the fall to the ocular recognition of nudity that immediately follows. Rather than direct the reader's attention to the "plot" of original sin or to the carnal or spiritual consequences that will ensue from it, he connects vision with knowledge and awareness. The text establishes a link between vision and knowledge; carnal knowledge is explicitly figured as a visual phenomenon.

Lest the reader be misled into believing that knowledge is positively implicated, Calvin continues, setting up his first contradiction: "Il faut dire que les yeux d'Eve furent bandés jusqu'à ce que son mari aussi fût trompé ... ils commencent à sentir leur mal ... Ils sont honteux de se voir nus" (Ancien

\footnotetext{
Ceulx qui l'ont appellée concupiscence n'ont point usé d'un mot trop impertinent, moyennant qu'on adjoustast ce qui n'est concedé de plusieurs: c'est que toutes les parties de l'homme depuis l'entendement jusques à la volunté, depuis l'ame jusques à la chair, sont souillées et du tout remplies de ceste concupiscence, ou bien, pour le faire plus court, que l'homme n'est aultre chose, de soymesme, que concupiscence (p. 260).
}

\footnotetext{
Those who have called original sin "concupiscence" have used a word not too unfitting, provided that they add what more than a few others do not concede: that all the parts of a person, from the understanding to the will, from the soul to the body, are tainted and completely filled with this concupiscence; or better, to speak more briefly, that people of themselves are nothing but concupiscence and wicked desires.
}

The English translation (above) is from Jean Calvin, Institutes of the Christian Religion (1541 French Edition), trans. Elsie Anne McKee (Grand Rapids, Michigan: William B. Eerdmans Publishing Company, 2009), p. 53. See also pp. 34-38. All further translations are from this edition.

7. This and all subsequent translations of Ancien Testament are mine. 
Testament, 74; We must note that Eve's eyes had been bound up until her husband, too, had been deceived ... they begin to feel their transgression ... they are ashamed to see themselves [each other; themselves seeing each other] naked). At first, it would seem as though Calvin is again linking original sin with knowledge; he explains that Eve's eyes are uncovered as soon as Adam partakes of the forbidden fruit. By thrusting nudity onto centre stage, Calvin is able to reconfigure what it means to know. But in the end, he returns again to his ultimate conclusion: the loss of divine knowledge completely eclipses any benefit that might be gained from human knowledge.

It is here that Calvin's treatment of knowledge enters a full-fledged representational paradox. Not only is vision the mechanism by which humans gain carnal knowledge, it is also to blame for this same acquisition. ${ }^{8} \mathrm{He}$ describes the fall into sin as one of visual recognition, since Eve's prelapsarian eyes were closed to carnal knowledge. After the fall, Adam and Eve are ashamed, not because of their actions, or because of their falling away from God, but because they see each other naked. The formulation of this particular phrase also implies that shame comes from being seen naked and thus from recognizing one's own nudity in the eyes of another person. Postlapsarian shame comes from being seen as much as it does from seeing. ${ }^{9}$ While nudity holds a signifying power and takes over much of the discussion of original sin, it is overshadowed in this passage by recognition of nudity that stems from sight. Calvin explicitly

8. For a more detailed analysis of Calvin's criticism of the eyes, and of the relationship between vision and clothing in sixteenth-century Geneva, see Graeme Murdock, "Calvin, Clothing, and the Body," Proceedings of the Huguenot Society 28 (2006), pp. 481-94, esp. pp. 483-85.

9. Valerie Allen uses the Middle English definition of blushing to uncover the roots of postlapsarian shame: "Middle English blishen means to shine brightly, to blush red, and to gaze upon, suggesting strongly that blushing comes less from being looked at than from looking, that Adam and Eve's shame came from seeing the other's nakedness rather than from exposure of self; hence, that to blush means to know, to see" (p. 205). Etymologically, Allen links shame to the action of seeing. While Calvin insists more on the implications of being seen, the interaction between the two-seeing oneself being seenadds to the complexity of postlapsarian shame as something that is simultaneously active and passive. See "Waxing Red: Shame and the Body, Shame and the Soul", in The Representation of Women's Emotions in Medieval and Early Modern Culture, ed. Lisa Perfetti (Gainesville, FL: University Press of Florida, 2005), pp. 191-210. For more about the explicitly human character of shame, see also Brian Cummings, "Animal Passions and Human Sciences: Shame, Blushing and Nakedness in Early Modern Europe and the New World," in At the Borders of the Human: Beasts, Bodies and Natural Philosophy in the Early Modern Period, ed. Valerie Fudge (New York: Palgrave, 2002), pp. 26-50. 
draws together the concepts of knowledge and nudity, but only represents them in terms of negative awareness.

During and after the fall, Calvin writes, Adam and Eve are subject to "[un] aveuglement horrible" (Ancien Testament, 65). Here, then, arises another paradox: seeing nudity is now not only a symptom of disobedience and corruption but it also leads to blindness. Rather than emphasize vision as a revelatory mechanism leading to awareness or knowledge, sight is now obliterated, turned into its opposite. Thus while the eyes might have been opened to nudity, this recognition of the body pales in comparison to the irreversible blindness associated with removal from divine knowledge. Calvin's immediate concern, of course, is with the fall from divine knowledge that ensues from original sin. But the loss of knowledge only takes place in the moment of visual carnal recognition. The tension between vision and blindness is bound up in the paradox of negative awareness after the fall, and it results in knowledge that is also negatively coded.

After Calvin establishes the paradox of negative knowledge that proceeds from original sin, he moves on to the problem of consequences. When Adam and Eve see their nudity, they quickly move to cover their genitals, thus textually marking certain body parts as shameful. Calvin insists that shame is a visual phenomenon, and he continues to use visual vocabulary to gloss the way in which Adam and Eve have been permanently marked by sin. He writes,

Adam et Eve ne se couvrirent point la face mais seulement les parties honteuses ... il fallait considérer qu'ils n'avaient pas une moindre cause de honte en leurs yeux et en oreilles qu'en leurs génitoires qui n'étaient point encore souillés par le péché ... mais il suffisait à Dieu que quelque marque de honte apparît dans le corps humain qui nous avertît du péché. Et puis, nous l'avons déjà dit, Adam et sa femme ne connaissaient pas encore leur vilenie quand ils s'effoçaient de fuir le regard de Dieu par une couverture si légère. (Ancien Testament, 75-76) $)^{10}$

10. "Adam and Eve did not cover their faces but only their shameful parts ... one must concede that they did not carry less shame in their eyes and ears than in their genitals that had not yet been stained by $\sin$... but it was enough for God that some mark of shame should appear on [in] the human body that should give us warning against sin. And so, as we have already said, Adam and Eve did not yet know the depth of their villainy when they tried to flee from God's sight with such a light cover." 
The passage above raises interesting points about the role of vision in identifying shame. Calvin writes that the marking of one body part, the genitals, should suffice to remind humans of their sin. ${ }^{11}$ The "parties honteuses," which function as a metonymy for sin itself, must now be covered in order to deter humans from further sin, presumably by removing the visual stimulus of these organs. This choice implies that Adam and Eve can now see the truth with the naked eye.

Although ultimately Calvin emphasizes their blindness towards their own sin and underscores the corruption of the entire body, he explicitly states that Adam and Eve leave their faces and eyes uncovered so that they might look upon their sin. And in order that they be easily able to access the memory of what they have done, God literally marks the naked body with visual signs of shame. The genitals, body parts previously as neutral as any other, are transformed into "marques de honte." Calvin's insistence that the coverings paradoxically mark what they seek to hide represents yet another paradox in which nudity and knowledge are involved. The inscription of sin onto the body ensures that shame will forever be a visually-identifiable phenomenon; at the same time, its very visuality links it to the negative awareness (blindness) of God's knowledge. Calvin contrasts the blindness that marks humans so paradoxically with God's own perfect vision and knowledge. He writes that Adam and Eve do not yet recognize the gravity of their sin when they try to flee "le regard de Dieu." Covering the naked body with leaves doubly marks the truth. ${ }^{12}$ It reveals the shameful nature of the postlapsarian human and underscores the futility of hiding from God's own perfect sight.

Calvin next goes on to describe the moment in Genesis when God provides more reliable clothing for Adam and Eve. But despite the thick animal

11. Calvin notes the absurdity of the notion that Adam and Eve would try to cover themselves with leaves: "Ç’a donc été une chose ridicule de mettre une telle couverture devant les yeux de Dieu. Cependant nous sommes tous entachés de ce même vice, car, aux premiers aiguissons qui nous poignent la conscience, nous tremblons et avons quelque honte" (Ancien Testament, 75; It was ridiculous to choose such light clothing when appearing in God's sight. And yet we are sullied by the same vice today, since we tremble and are ashamed by even the slightest jolts to strike the conscience).

12. In the case of the male, the mark is even more visually accessible than for the female, since erections are nothing if not betrayals of the lust caused by original sin. St. Augustine of Hippo (ca. 354-430) makes this point explicitly; see, for example, Augustine: The City of God against the Pagans, ed. and trans. R. W. Dyson (Cambridge: Cambridge University Press, 1998), book 14, chapters 15-19. 
skins with which he provides them, God's protective gift only further underscores Calvin's representational problem of depicting postlapsarian knowledge negatively. Reflecting on the choice of animal furs specifically, he writes, "Dieu a donc voulu que les premiers hommes, en étant en un tel habit, vissent leur vilenie, tout comme ils l'avaient vue auparavant en leur nudité, et que par ce moyen ils eussent souvenance de leur péché" (Ancien Testament, 76, emphasis mine; By giving them this kind of apparel, God thus wanted the first humans to recognize their villainy, just as they had done so before when confronted by their nudity. In this way, he wanted them to remember their sin). Seeking to underscore the bestiality of mankind after the fall, Calvin writes that Adam and Eve must see their villainy. Then he links present and future shame to the first moment when "ils l'avaient vue ... en leur nudité." Immediately after the fall, Adam and Eve's nudity marked them and made them ashamed. Looking upon nudity, or on the symbolic coverings of animal furs, helped them to remember their lustful nature and helped them to keep their true nature under wraps. As above, in the case of the marked genitals, Calvin underscores here that the postlapsarian truth of human corruption is visibly etched into the human body, and is made even more visible by the absence of nudity. The human body and human sight trigger negative knowledge and recognition of sin (which Calvin calls a kind of blindness). Nakedness is the harbinger of corruption: it reveals the ever-present "aveuglement horrible" into which mankind has fallen, but only by seeing nudity (or its inscription) can they understand it.

Adam and Eve have always been naked, but their fall into sin transforms nudity-an exterior phenomenon-into the visualization of the corrupt interior. By etching shame onto the naked body, Calvin implies that too much is written on the surface of postlapsarian man. And he warns that so many centuries after the fall, these original mechanisms are not enough to prevent true human nature from seeping to the surface. Corruption and culture have removed or weakened the visual reminder of clothing; Calvin laments at length the gaudy excessiveness with which many of his contemporaries increasingly cover themselves. ${ }^{13}$ Sixteenth-century Europeans, Calvin implies, are blind to their own blindness. Humans must cover themselves up-blind themselves to nakedness - at the same time as seeing these coverings will, and must, remind

13. Graeme Murdock outlines these regulations at length in "Dress, Nudity and Calvinist Culture in Sixteenth-Century France," Clothing Culture, 1350-1650 (Burlington, VT: Ashgate, 2004), pp. 123-36, p. 130. 
them of the negative knowledge that their covered bodies represent. In this way, clothing actually depicts a kind of nakedness. By the same token, nudity is transformed into a representation of the prelapsarian state of innocence. If bodily nudity is coded negatively after the fall, the clothed body in the sixteenth century is just as ineffective in preventing corruption, because human nature "will out" at all costs.

Calvin desperately seeks the best way to represent the human blindness that takes place after the fall, so that he can warn his fellow citizens of the perils that lurk beneath the veil of fabric or fur. He advises his readers as to how they might cope with the postlapsarian imperfections of man:

Dont il advient que en tant que nous sommes encore bien loing de la perfection, il nous est mestier de proffiter journellement; et en tant que nous sommes enveloppez en beaucoup de vices, qu'il nous est mestier de batailler à l'encontre. De là s'ensuit qu'il nous fault veiller diligemment pour nous garder d'estre surpris des trahisons de nostre chair. (Institution, $340-41)^{14}$

If, in Calvin's own words, original sin leads to blindness, watchfulness against an impending betrayal of the flesh seems impossible. And yet Calvin chooses a visual metaphor here to describe man's struggle against postlapsarian vice. Calvin operates under the assumption that humans do not know what is going on underneath the surface. Because he is convinced that postlapsarian man is fundamentally evil, Calvin advises his fellow men and women to be on their guard in order to spot the signs that might betray them. Clothing, for Calvin, is man's last defense against the corrupt flesh that has been permanently and visually inscribed by original sin. He hopes that it will provide a protective shield with which to block the lust and carnal knowledge that lurk just underneath. At the same time, however, the very presence of clothing represents the very blindness that the postlapsarian self is trying to hide. The absence of nudity marks the absence of knowledge as well. Clothing reminds mankind of her nakedness and shame that accompany the lost innocence of Eden; it represents the paradoxical knowledge that both accompanies original sin and is lost by it.

14. "Since we are still quite far from perfection, it is our job to advance daily; and since we are tangled up in many vices, it is our job to fight against them. From that it follows that we must be diligently watchful, on guard against being surprised by the betrayal of our flesh" (p. 93). 
Intentionally or not, Calvin's stance on nudity reflects the same anxiety of representation present in so many secular writings of the sixteenth century. Despite his very best intentions, the Reformer's text takes off in the opposite direction from the point he is trying to prove. The implications of nudity go beyond that which the body is able to represent; the corrupt nature of humankind is just as present in its clothed state as in its naked one. Adding layers of clothing does nothing to cover the stain of original sin. Nudity is unavoidable; no matter what is added to the naked body, the true essence of humanity is too legible. Though Michel de Montaigne takes on the problem of nudity from a very different angle, he will face the same problem of representation. If Jean de Léry is interested in determining whether or not the naked inhabitants of the New World have fallen from grace, humanist writers such as Michel de Montaigne will look to New World nudity for clues about the very nature of what it means to be human. The move from "Reformation" to "Renaissance" is an artificially-constructed one; indeed, it would be difficult to think about human nature in the sixteenth century without considering matters of grace and the fall. In other words, the relationship between Calvin and Montaigne's writings on nudity should not be read as one that gradually ascends from religious to secular. Instead, Calvin's conclusions about nudity help readers to understand Montaigne's own frustrations with rhetorical, textual, and societal failures to produce and represent the naked truth.

\section{Montaigne's textual striptease}

If Calvin's narrative of human nudity focuses on original sin and the knowledge that comes and goes along with the fall, Montaigne explicitly does not. It hardly comes as a surprise that he turns to the inhabitants of the New World and not, like Calvin, to the biblical setting of postlapsarian Eden. ${ }^{15}$ Though significant work has been done on Montaigne's attempt to remain largely secular in his writing (despite his occasional job as negotiator between religious factions in the French Wars of Religion), the enticement of nudity in Eden and the New

15. Throughout his essays, Montaigne eclipses the moment of original sin, though he includes many other examples-of a classical, scientific, and personal nature-of nudity. Some scholars used this omission to explain Montaigne's views towards religion (another way in which to separate him from Calvin). See, for example, R. Hoopes, "Fideism and Skepticism during the Renaissance: Three Major Witnesses," The Huntington Library Quarterly 4 (1951), p. 136. 
World invites a second look at potential connections between Calvin's and Montaigne's versions of the natural-and naked-state of humanity. ${ }^{16}$

Montaigne does not shy away from representing the nudity of "savages." In so doing, he effectually writes over original sin, composing his own narrative of nudity. In "De l'usage de se vestir" (Essais I: 36), he introduces his theme with a reflection: "Je devisoy, en cette saison frileuse, si la façon d'aller tout nud de ces nations dernierement trouvées, est une façon forcée par la chaude temperature de l'air ... ou si c'est l'originele des hommes" (1:36.327; I was wondering in this shivery season whether the fashion of going stark naked in these lately discovered nations is forced on them by the warm temperature of the air, as we say of the Indians and Moors, or whether it is the original way of mankind, p. 166). ${ }^{17}$ Montaigne traces the last bastion of the natural state of man to those recently discovered "savages" in the New World. Reasoning that "il s'en trouve d'assises environ sous même ciel que le nôtre" (328; there are some situated under much the same sky as ours, p. 167), Montaigne comes to the conclusion that it cannot be against nature to go about naked. Comparing our natural clothing to that of the rest of creation, he cites from Lucretius's Of the Nature of Things: "Proptereaque fere res omnes aut corio sunt, / Aut seta, aut conchis, aut callo, aut cortice tectae" (4:936; And therefore everything is covered oer / With either hide, silk, shells, thick skin, or bark, p. 167). The skin, presumably, is the protective shell that allows mankind to live naked in her most natural state. According to Calvin, this natural state was spoiled by vision and the ensuing sensation of shame, but Montaigne points to a different culprit: "comme ceux qui éteignent par artificielle lumière celle du jour, nous avons éteint nos propres moyens par les moyens empruntés" (328; like those who by artificial light extinguish the light of day, we have extinguished ours by borrowed means, p. 167). Calvin and Montaigne both criticize sixteenth-century clothing, albeit for different

16. See, for example, Michael Allen Gillespie, “Montaigne's Humanistic Liberalism,” The Journal of Politics 47 (1985), pp. 140-59; George Hoffmann, “Anatomy of the Mass: Montaigne's 'Cannibals.” PMLA 117 (2002), pp. 207-21; or Gérard Defaux, "Une leçon de scepticisme: Montaigne, le monde et les grands hommes," MLN 116 (2001), pp. 644-65. For an overview of the intersection between philosophy and religion in the period, see Paul Richard Blum, ed., Philosophy of Religion in the Renaissance (Burlington, VT: Ashgate, 2010).

17. English translation from The Complete Essays of Montaigne, trans. Donald M. Frame (Stanford: Stanford University Press, 1958). All further translations will be from this edition unless otherwise noted. 
reasons; whereas Calvin claims that it distracts from the message of postlapsarian bestiality, Montaigne ascribes it to culture, trying to leave the naked body itself free from the judgment that Christian narrative repeatedly casts on the postlapsarian flesh. ${ }^{18}$ Montaigne critiques the fashion among his contemporaries to conceal their true natures. One's natural qualities are hidden in the murky waters beneath the surface of the skin, cloaked in artifice and layers of cloth. In other words, custom, culture, and an overly zealous interest in fashion have diluted one's ability to go without clothing and, by extension, to really see oneself through the cipher of nudity. As a participant of the culture about which he writes, however, Montaigne inscribes himself into the same tradition; the textual absence of nudity reveals just as much as actual nudity itself might. While he promotes the nudity of New Worlders as a sincere, natural state, any potential interpretation of nudity is erased by Montaigne's evasion of it. Thus, while Calvin relies upon visual imagery in order to make a case for blindness, Montaigne uses the discussion of nudity as an artificial trope, employing it to tell his readers what they will not see. His representations of exposure stand in for actual sight.

The closing sentences of "Des Cannibales" (I:31), one of the most-read and most-studied of his essays, further underscores Montaigne's precise irony, and it provides clues as to how to decipher the perplexing contradiction between what the essayist says and what he does in his writing. As in "De l'usage," Montaigne typifies savages by their lack of civilized dress. If the essay focuses on customs and daily habits rather than the bodily elements of savage life, a twist at the end subverts Montaigne's already ironic reading of the cannibals' savagery: “Tout cela ne va pas trop mal," he writes, referring to the privileges granted to a native man with whom he has spent some time, "mais quoy? ils ne portent point de haut de chausses" (314; All of this is not too bad-but what's the use? They don't wear breeches, p. 159). Does the ambiguity of "tout cela" refer to these privileges, or to the entire essay? The opacity of Montaigne's meaning throws the balance of the entire project into uncertainty. Suddenly shifting the reader's attention to the cannibals' lack of clothing undermines the "normalcy" of their behaviour underscored in the preceding paragraphs. If nudity was not the leading factor

18. Against a long line of early Christian commentaries on the original sin that takes place in Genesis (most famously described by St. Augustine in The City of God Against the Pagans), Montaigne goes out of his way to make the opposite case on p. 133 of Sur des Vers de Vergile: "Quel monstreux animal qui se fait horreur à soy mesme" (What a monstrous animal to be horror to himself, p. 670). 
in all parts of the essay, it bursts back onto the scene in the very last lines. Most scholars have interpreted this essay as an ironic commentary on the savagery of sixteenth-century French society, using the cannibals of the New World as a rhetorical foil. ${ }^{19}$ If this reading holds true, then nudity, and its auspicious appearance at the very end of the essay, enhances the reader's ability to recognize Montaigne's veiled message. By inserting nudity at a key moment in the text, and by pointing out the nakedness of a foreign culture, the author exposes his own society, if only to show that the artifice of which he spoke earlier prevents him from revealing as much as he would like. The subtle mechanism by which he accomplishes his critique underscores the extent to which exposure and concealment are at play in this essay, as in many of his others.

Montaigne's awareness of his own culture's foibles, which he so deftly cloaks in the nudity of the "savages," raises red flags when the reader thumbs back to the author's preface "Au Lecteur," in which he claims that were he not prevented from doing so by "coustume," he would paint himself "tout entier, et tout nu" (49). ${ }^{20}$ To readers encountering the Essais for the first time, it might seem that Montaigne unconditionally associates nudity with freedom and sincerity. ${ }^{21}$ But those more familiar with the essays that follow, and with their author's famous ability to apply irony to almost any situation (particularly in light of the passages discussed above), know to mull over this claim with several grains of salt. Notably, Montaigne does not paint himself "tout entier, et tout nu." He says he would prefer to strip down naked and expose every bit of himself, but he then explicitly steps back from his proposition. Throughout the Essais, Montaigne teases his readers with a glimpse or promise of revelation, but he then turns this promise into dissimulation. I believe that Montaigne's

19. For two examples, see Roger Celestin, "Montaigne and the Cannibals: Toward a Redefinition of Exoticism," Cultural Anthropology 5, no. 3 (1990), pp. 292-313; and George Hoffmann, "Anatomy of the Mass: Montaigne’s 'Cannibals,'” PMLA 117, no. 2 (2002), pp. 207-21.

20. Essais I (Paris: Gallimard, 1965). All further quotations are from the same volume and/or edition unless otherwise indicated. Cited hereafter in text.

21. Scholars have mulled over this phrase and its meaning, coming to varying conclusions about the author's sincerity and intentions. For a few examples, see p. 128 in Frank Lestringant, “'De l'usage de se vestir' (Essais, I:36): Variations sur le nu et le vêtu," in Les Chapitres oubliés des Essais de Montaigne, ed. and intro. Philippe Desan (Paris: Honoré Champion, 2011); and p. 128 in Jonathan Kim-Reuters, “The Body's Eye: On the Origins of Self-Observation in Montaigne's Essays," Explorations in Renaissance Culture 35 (2009), pp. 220-43. 
invocation of nudity serves as a rhetorical substitute for actually de-robing. ${ }^{22}$ Unlike Calvin's completely sober frustration with the exposure that goes along with nudity, however, Montaigne's playful refusal to strip down textually enacts the essayist's larger frustration with his inability to distill the essence of the human experience. Indeed, references to nudity highlight the inability to strip down the self to what actually matters.

If Montaigne's interest lies in finding out the "original natural qualities of man," then he should, theoretically, be prepared to lead by example, as he claims that he will do in his preface to readers. But his writing demonstrates, more than anything else, the difficulty of his self-stated project. Consider the following citation, which includes a bit more of the passage that ends with his expressed desire for self-exposure:

Je veux qu'on m'y voie en ma façon simple, naturelle, et ordinaire, sans contention et artifice: car c'est moy que je peins ... Que si j'eusse este entre ces nations qu'on dict vivre encore sous la douce liberté des premieres loix de nature, je t'asseure que je m'y fusse tres-volontiers peint tout entier, et tout $n u$. (“Au Lecteur," 49; emphasis mine) ${ }^{23}$

For Adam and Eve, the first glance at each other results in shame and blindness to God's knowledge at the same time as their eyes are opened to sin. Montaigne advocates for the opposite perspective. Glimpsing his naked self will result in truth, in a simple discerning of the real, in a removal of artifice. Sight, and its association with the naked body, is for Montaigne a reunion of interior and exterior. The body, for Montaigne, consists of what Jonathan Kim-Reuters has called a "consubstantiality" between "inward sense and outward profile." Once revealed, all will be legible. ${ }^{24}$

22. For a more thorough discussion of nudity in Montaigne's preface, see pp. 128-33 in Lestringant; and Emily Jo Strunks, “The Metaphors of Clothing and Nudity in the Essais of Montaigne," Romance Notes 19, no. 1 (1978), pp. 83-89.

23. "I want to be seen here in my simple, natural, ordinary fashion, without straining or artifice; for it is myself that I portray ... Had I been placed among those nations which are said to live still in the sweet freedom of nature's first laws, I assure you I should very gladly have portrayed myself here entire and wholly naked" (3).

24. The underlying premise of Kim-Reuter's argument is that despite all efforts to make the Essais reflections of interiority, they are, above all, embodied. See p. 221 in “The Body's Eye." 
Readers need not assume that Montaigne is willingly hiding behind the curtain. Nudity, for Montaigne, involves, as it did for Calvin, a frustration of sight-but for the philosopher, the frustration lies in what cannot be seen instead of in the problems associated with seeing too much. Like Calvin, Montaigne agrees that humans are created with a fixed set of qualities and traits. However, if for Calvin these qualities are inherently bad, needing to be covered and concealed, Montaigne implies that humans conceal their natural qualities as the result of their own choice or custom. If clothing is a necessary evil for postlapsarian man and woman in the Reformer's world, Montaigne implies instead that concealment of our true nature leads to more harm than good. In "Du Repentir," Montaigne writes that "on n'extirpe pas ces qualités originelles, on les couvre, on les cache" (3.2.51; We do not root out these original qualities, we cover them up, we conceal them, p. 615). ${ }^{25}$ While natural qualities may be easily covered, this process renders it comparatively difficult to see below the "filets et pointes d'eau fine rejaillies d'un fond au demeurant limoneux et pesant" (3.2.50; thin streams and jets of water spurting from a bottom otherwise muddy and thick, p. 614). The result, predictably, remains murky. Rather than draw the readers' sight to any kind of naked truth, Montaigne uses the very idea of nudity, and the connotations of purity with which he has instilled it (however ironically), as a screen with which to cover himself. This action of feigned bareness repeats itself on a textual level; the mere possibility of glimpsing anything underneath the sardonic textual striptease is rendered impossible by the act of reading, since words have nothing inherently to do with nudity, and since a text cannot be naked. For Montaigne, then, nakedness acts as a textual and contextual cover for never-ending veils of epistemological confusion. In the end, these layers of purported nudity reveal only more layers of dissimulation.

Montaigne does not let his readers forget that he, the author, will stand trial in front of the ultimate reader of human hearts. For as much as the essayist evades painting himself "tout entier, et tout nu" to his readers, he makes it clear that God, "ce grand juge," will penetrate his "virginale pudeur." He writes, "rechargeons notre dette envers ce grand juge qui trousse nos panneaux et haillons d'autour nos parties honteuses, et ne se feint point à nous voir par tout, jusques à nos intimes et plus secrètes ordures. Utile décence de notre virginale pudeur,

25. Essais III (Paris: Gallimard, 1965). All quotations from this essay are from this edition. Cited hereafter in the text. 
si elle lui pouvait interdire cette découverte." (3.5.145; we rather add our debt to that great Judge who tucks up our rags and tatters from around our shameful parts and does not merely pretend to see us throughout, even to our inmost and most secret filth. Our virginal modesty would be a useful propriety if it could keep him from making this discovery, p. 677).

If Montaigne plays a textual game of striptease with his readers, constantly offering and withholding nudity, always clouding the vision of those looking upon him with a new substitution for actual nudity, he cannot evade the knowledge that God will look upon him as he really is. ${ }^{26}$ At first glance, this would actually seem to align him quite closely with Calvin, who writes that humans can never hide their nakedness from the eyes of God (who will always see them for the sins they commit). Calvin counsels his readers to beware self-exposure, writing that signs of internal betrayal can appear on the naked exterior of the body without warning. Montaigne seems less concerned about external nudity; instead of coding it as exposure, which implies loss of control, he explicitly seeks to cast the internal experience as something worthy of revealing in all of its nude glory. But when it comes to stripping down in front of God, a process that happens on the interior, Montaigne suddenly appears cautious. Montaigne specifically refers to his "parties honteuses," and to "nos intimes et plus secrètes ordures." These are parts of himself that Montaigne wishes to keep hidden from God if he possibly can, though elsewhere he shows no shame in seeking to represent them to his readers. If Calvin's readers must constantly be on guard against potential exposures of the corrupt self on the outside, Montaigne must beware betrayals of himself to God. The difference is that these parts are on the

26. See also "Du Repentir," in which Montaigne uses carnal imagery in order to describe the complicated and, as he writes, apparently "grievous" effects of repentance:

La malice hume la plupart de son propre venin et s'en empoisonne. Le vice laisse, comme un ulcère en la chair, une repentance en l'âme, qui toujours s'égratigne et s'ensanglante ellemême. Car la raison efface les autres tristesses et douleurs; mais elle engendre celle de la repentance, qui est plus griève, d'autant qu'elle naît au-dedans; comme le froid et le chaud des fièvres est plus poignant que celui qui vient du dehors (3.2.46; Malice sucks up the greater part of its own venom, and poisons itself with it. Vice leaves repentance in the soul, like an ulcer in the flesh, which is always scratching itself and drawing blood. For reason effaces other griefs and sorrows; but it engenders that of repentance, which is all the more grievous because it springs from within, as the cold and heat of fevers is sharper than that which comes from outside, p. 612). 
interior, safely tucked away from the sight of his readers. Montaigne contradicts himself repeatedly, then, claiming in "Du Repentir" that our natural qualities may be covered and hidden, but not from God. If he wishes to hide "nos intimes et plus secrètes ordures" from God, he apparently seeks to reveal them "sans contention et artifice" to his readers.

But because he never tells readers what secrets he is referring to, the purported nudity in God's eyes also remains safely tucked out of sight. Montaigne's game leads only to more rhetorical dead ends. Sometimes he plays hide-andseek with his readers, expressing his wish to reveal all but never doing so. At other moments, Montaigne hints at complete exposure when he references the inability to hide certain secrets from God. And by completely eclipsing the narrative of original sin, preferring instead to overwrite the Christian narrative of nudity with a secular version, Montaigne once again participates in practices of nudity and concealment just as he disavows them. In the end, the reader is left with nothing more or less than often-conflicting words, which, of course, cannot be stripped down any further. Montaigne's text, and the method in which he constructs it, supports Andrea Frisch's hypothesis that "the potential meaning of the body is not legible on the body" (147; emphasis in original); ${ }^{27}$ nakedness, whether physical or metaphorical, can point to true exposure, or to a withheld promise, or to the desperate wish to hide.

The long essay "Sur des Vers de Vergile" (3:5) further highlights Montaigne's vacillation between exposure and concealment, and ties together the many acts of Montaigne's textual and meta-textual striptease. In Lawrence Kritzman's words, “throughout most of 'Sur des vers de Virgile', Montaigne expresses the desire for absolute frankness in both sexuality and rhetoric. The nudity and transparency made operative through the essaying process require an external projection of the internal." ${ }^{28}$ However, I would add that the exchange between internal and external takes place by an intermingling of nude and clothed figures, a process that renders the boundary between nudity and

27. Frisch is writing about the dissemination of Calvin's views on the Eucharist in the New World. See "Presence," in The Invention of Eyewitness: Witnessing and Testimony in Early Modern France, North Carolina Studies in Romance Languages and Literatures 279 (Chapel Hill: University of North Carolina Press, 2004), pp. 141-80.

28. Lawrence Kritzman, "My Body, My Text: Montaigne and the Rhetoric of Self-Portraiture," in The Rhetoric of Sexuality \& the Literature of the French Renaissance (Cambridge: Cambridge University Press, 1991), pp. 131-48, p. 143. 
clothing "indistinguishable." ${ }^{29}$ Early in the essay, Montaigne exclaims, "Je veux être maître de moi, à tout sens" (3.5.87). Mastering oneself is not congruent with painting oneself "tout entier, et tout nu." Later, he backs up on the claim to self-mastery, trying again to stake out a claim for honesty: "je dois au public universellement mon portrait" (144; I owe a complete portrait of myself to the public, p. 677). Or: "Il est à cette heure temps d'en parler ouvertement" (147; It is time now to speak of it openly, p. 679). This proclamation comes more than halfway through the essay, and more than halfway through his oeuvre as a whole-not exactly in line with his claim on the very first page to expose himself completely. In fact, Montaigne states early in this essay that "Venus n'est pas si belle toute nue" (97; Venus is never so beautiful stark naked, p. 958). ${ }^{30}$ Here, nudity poses a challenge, as it did for Calvin, and again it is a problem of exposure. Read in the context of Montaigne's claim that he wishes to, but cannot, paint himself completely naked, and in the wake of his statement that true nature can be all too easily concealed, readers are again presented with a contradiction. Is naked Venus less beautiful because some of her faults are exposed? Or does partially clothing her, as Montaigne partially clothes himself, uphold the mystery of what lies beneath? Does Montaigne seek to shed light on true human nature in its most naked, or its most advantageous light? None of these questions can be answered univocally when they are considered together with the passages from his other essays, but Montaigne's appraisal of Venus serves as a powerful indicator of the writer's fascination with the dialogic movement between concealment and exposure that prevents him, for whatever reason, from completing a nude portrait of himself.

Complete concealment, or even partial nudity, is much easier to track down than a complete stripping down, a revelation ironically and repeatedly reflected in Montaigne's technique as much as his content. In the end, Montaigne's frustration is as much a textual as a representational one; caught in his own words, the essayist cannot distill human knowledge despite his self-stated desire to do so. Thus while appearances emerge a dime a dozen, complete nudity, and therewith truth, remains "si loin [de la] visée" (3.2.50; so far out of sight [translation mine]).

In the end, Calvin's stance on nudity underscores the blindness brought about by original sin, though it relies on images of clothedness and carnal 
knowledge to do so. The paradox of representation in Calvin's language surrounding original sin, shame, and knowledge takes place textually and cannot be reliably linked to Calvin's own thinking about the body. The Reformer's primary concern is that the clothing on the surface will fail to block the true nature it hides underneath. Significantly, Michel de Montaigne will make the opposite argument. He explicitly wants to discover what it means to be "tout nu," but despite various techniques of stripping down, he finds it impossible to attain nakedness underneath the suffocation of custom and artifice. His futile attempts to strip down thus suggest a kind of representational limit to how much a text can expose. Though they come to opposite conclusions about what it means to be human, both indicate that the naked truth cannot be found on the naked body in any straightforward way.

In a complex series of paradoxes, the reliance on visual imagery highlighted by both Montaigne and Calvin points to the instability of human knowledge. ${ }^{31}$ A naked Venus represents different things, and different kinds of knowledge, to both authors, but neither one of them wants her completely naked. Trying to undo negative human knowledge in the face of postlapsarian nudity involves a representational tangle not dissimilar to Montaigne's attempt to find nudity, which he associates with positive knowledge. In both cases, sight plays a central role in the problem of representing naked knowledge. And despite its central role in early modern discourse, vision seems to ricochet when it encounters nakedness. In Calvin, it bounces back and leads to blindness in the face of God. Both writers use the tropes of vision and nakedness to turn knowledge on its head. Sight is transformed into blindness. What Stephen Pender calls the "triumph of visuality" in the early modern period lies perhaps not so much in what it reveals but rather in the new kinds of ambiguities it creates. ${ }^{32}$ Thus for Calvin, seeing nudity is equated with the disgraceful exposure of corrupt human nature after original sin. For Montaigne, true nudity, were it possible, would reveal rather than expose. The lamentable inability to see through the murky waters of human nature renders such clairvoyance impossible. Montaigne rhetorically compensates for this frustration by engaging in a textual game of striptease. While the distance between the respective over- and under-exposure of each

32. Stephen Pender, "Signs of Interiority, or Epistemology in the Bodyshop," Dalhousie Review 85 (2005), pp. 221-37, p. 223. 
author remains too great to truly bring them together, the exchange between nudity and vision, for both writers, develops into something productive and ambiguous, and it highlights the continued epistemological crisis in sixteenthcentury religion, culture, and writing. 